\title{
Transgenerational memory of gene expression changes induced by heavy metal stress in rice (Oryza sativa L.)
}

Weixuan Cong ${ }^{1 \dagger}$, Yiling Miao ${ }^{1 \dagger}$, Lei X $u^{1 \dagger}$, Yunhong Zhang ${ }^{1}$, Chunlei Yuan ${ }^{1}$, Junmeng Wang ${ }^{1}$, Tingting Zhuang ${ }^{1}$,

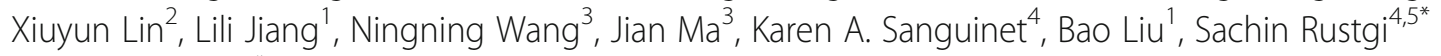
and Xiufang $\mathrm{Ou}^{1 *}$ (D)

\begin{abstract}
Background: Heavy metal toxicity has become a major threat to sustainable crop production worldwide. Thus, considerable interest has been placed on deciphering the mechanisms that allow plants to combat heavy metal stress. Strategies to deal with heavy metals are largely focused on detoxification, transport and/or sequestration. The $\mathrm{P}_{1 \mathrm{~B}}$ subfamily of the Heavy Metal-transporting P-type ATPases (HMAs) was shown to play a crucial role in the uptake and translocation of heavy metals in plants. Here, we report the locus-specific expression changes in the rice HMA genes together with several low-copy cellular genes and transposable elements upon the heavy metal treatment and monitored the transgenerational inheritance of the altered expression states. We reveal that plants cope with heavy metal stress by making heritable changes in gene expression and further determined genespecific responses to heavy metal stress.

Results: We found most HMA genes were upregulated in response to heavy metal stress, and furthermore found evidence of transgenerational memory via changes in gene regulation even after the removal of heavy metals. To explore whether DNA methylation was also altered in response to the heavy metal stress, we selected a Tos 17 retrotransposon for bisulfite sequencing and studied its methylation state across three generations. We found the DNA methylation state of Tos 17 was altered in response to the heavy metal stress and showed transgenerational inheritance.

Conclusions: Collectively, the present study elucidates heritable changes in gene expression and DNA methylation in rice upon exposure to heavy metal stress and discusses implications of this knowledge in breeding for heavy metal tolerant crops.
\end{abstract}

Keywords: Heavy metal stress, Transgenerational memory, Gene expression, DNA methylation

\section{Background}

Plants are sessile organisms and are often confronted with a variety of stress factors simultaneously, which can dramatically decrease their yield and quality. In the recent years, heavy metal pollution, i.e., contamination of the natural environment with cadmium $(\mathrm{Cd})$, chromium

\footnotetext{
* Correspondence: srustgi@clemson.edu; ouxf074@nenu.edu.cn ${ }^{+}$Weixuan Cong, Yiling Miao and Lei Xu contributed equally to this work. ${ }^{4}$ Department of Crop and Soil Sciences, Washington State University, Pullman, WA 99164, USA

'Key Laboratory of Molecular Epigenetics of MOE and Institute of Genetics \& Cytology, Northeast Normal University, Changchun 130024, China Full list of author information is available at the end of the article
}

$(\mathrm{Cr})$, copper $(\mathrm{Cu})$, mercury $(\mathrm{Hg})$, and zinc $(\mathrm{Zn})$ has become a global problem, affecting about 235 million hectares of the arable land worldwide [1]. Heavy metals compromise crop productivity and pose a threat to human health via heavy metal accumulation in the food chain [2]. In plants, heavy metals interfere with several metabolic processes including photosynthesis, water relations, and nutrient uptake, resulting in reduced plant growth, stunting, and in some instances, death $[3,4] . \mathrm{Cu}$ is an essential micronutrient; however, if present in excess it also causes toxicity to plants [5]. Cr is also a common metal contaminant in the Earth's crust. While

(C) The Author(s). 2019 Open Access This article is distributed under the terms of the Creative Commons Attribution 4.0 International License (http://creativecommons.org/licenses/by/4.0/), which permits unrestricted use, distribution, and 
naturally occurring, $\mathrm{Cr}$ does not cause toxicity to plants, but excessive amounts can cause injury [6]. $\mathrm{Cd}$ and $\mathrm{Hg}$ are both non-essential and toxic elements for plant growth and human health. These elements are almost ubiquitously present at low levels in the environment but have now started to accumulate due to anthropogenic activities. In its 25-year plan for the comprehensive prevention and control of heavy metals the Ministry of Environmental Protection of the People's Republic of China listed $\mathrm{Cd}, \mathrm{Pb}, \mathrm{Hg}$, and $\mathrm{Cr}$ as the major environmental pollutants, and pledged efforts to control their release to the environment (www.cleanairchina.org/file/ loadFile/9.html). Parallelly, in view of the public health concern, in the report on the National Food Safety Standard Limits on contaminants in food (GB 27622017) the National Standards of the People's Republic of China, made recommendations on the maximum tolerable amount of $\mathrm{Cu}\left(10 \mathrm{mg} \mathrm{kg}^{-1}\right), \mathrm{Cr}\left(1.0 \mathrm{mg} \mathrm{kg}^{-1}\right), \mathrm{Cd}$ $\left(0.2 \mathrm{mg} \mathrm{kg}^{-1}\right)$, and $\mathrm{Hg}\left(0.02 \mathrm{mg} \mathrm{kg}^{-1}\right)$ in rice grains.

Since heavy metal toxicity has become one of the major challenges in increasing crop productivity, investigating heavy metal tolerance genes and stacking them in a single genetic background, have become a major theme of plant breeding research. Over the course of evolution, plants have developed different strategies to overcome heavy metal toxicity. For example, relatively low levels of metals are present in shoots by either restricting translocation of toxic metals, sequestration to vacuoles, or detoxification [7-12]. Conversely, some plants have developed exceptional abilities to translocate and accumulate heavy metals in their aboveground organs [13].

Recent research has revealed that the $\mathrm{P}_{1 \mathrm{~B}}$ subfamily of Heavy Metal-transporting P-type ATPases (HMAs) play a crucial role in the uptake and translocation of heavy metals in plants $[14,15]$. There are eight and nine members of $\mathrm{P}_{1 \mathrm{~B}}$-ATPases in Arabidopsis thaliana and rice (Oryza sativa L.), respectively [16, 17]. Based on the metal-substrate specificity these ATPases can be divided into two subgroups: a zinc $(\mathrm{Zn}) /$ cobalt $(\mathrm{Co}) /$ cadmium $(\mathrm{Cd}) /$ lead $(\mathrm{Pb})$ group and a copper $(\mathrm{Cu}) /$ silver $(\mathrm{Ag})$ group [18]. In A. thaliana and rice, AtHMA1-AtHMA4 and OsHMA1-OsHMA3 belong to the former group whereas AtHMA5-AtHMA8 and OsHMA4-OsHMA9 belong to the latter group [18]. All members of the HMA family in A. thaliana have been functionally well characterized. The HMA family members exhibit differences in expression sub-cellular localization, and metal specificity and regulation, which all indicate unique functions within the gene family. For instance, AtHMA1, AtHMA5-AtHMA8 were reported to play a role in $\mathrm{Cu}$ homeostasis [19-22]. AtHMA2-AtHMA4 were involved in $\mathrm{Cd}$ translocation and sequestration [23-25]. In contrast, the rice HMA transporter family is not as well characterized. For instance, OsHMA1 and OsHMA9 were postulated to play a role in $\mathrm{Zn}$ transport $[26,27]$. OsHMA2 and OsHMA3 were reported to be involved in the transportation of $\mathrm{Cd}$ [28-30], OsHMA4 and OsHMA5 have a function in $\mathrm{Cu}$ transport, loading, and detoxification [31, 32]. However, little research has been performed on OsHMA6, OsHMA7, and OsHMA8.

Modulation of gene expression is one rapid strategy to respond to environmental stresses. It has been repeatedly shown that heavy metal stress induces changes in gene expression. For instance, transcript profiling of the Cd-tolerant cultivar of Chinese flowing cabbage revealed numerous changes in gene expression in response to $\mathrm{Cd}$ treatment including upregulation of $H M A 3$ and $H M A 4$ [33]. Research in Sedum plumbizincicola showed elevated expression of the SpHMA3 gene in response to $\mathrm{Cd}$ stress suggesting a role in $\mathrm{Cd}$ detoxification and normal growth of young leaves under Cd stress [34]. Similarly, in Lycopersicum esculentum, heavy metal transporters COPT1 and COPT2 could be induced to express under $\mathrm{Cu}$ stress [35]. Functional genomics tools have been extensively used to examine mechanisms conferring tolerance to various heavy metal stresses. In a recent report, genome-wide transcriptome analysis in rice showed dose-dependent changes in expression of metal ion transporter genes in response to Cd stress [36].

One way to maintain changes in gene expression is via epigenetic modification. Indeed, epigenetic variation contributes to phenotypic plasticity in response to the environmental changes [37]. In particular, DNA methylation is an important epigenetic marker, which regulates gene expression as an adaptive mechanism for survival under stress. In a recent study, genome-wide single-base resolution maps of methylated cytosines and transcript profile of Cd-treated rice was reported [38]. The study showed that most of the epigenetically regulated genes were transcriptionally activated under $\mathrm{Cd}$ stress, and many of these genes represent formerly characterized stress responders, metal transporters and transcription factors [38]. Despite initial progress, implementation of these epigenetic markers in plant breeding has stalled because the heritability of these makers has not yet been tested [37].

Since rice $(O$. sativa L.) is one of the major staple grains worldwide, increasing its productivity and nutritional quality is one of the foremost priorities. In the interest of ensuring food security and better nutritional quality, it is important to reduce the accumulation of toxic elements in rice grains $[39,40]$. A deep understanding of the genes responsible for the sequestration of toxic elements can enable the development of crop varieties with reduced content of these elements in the edible plant parts. Our previously, work has shown that heavy metal stress $(\mathrm{Cd}, \mathrm{Cr}, \mathrm{Cu}$, and $\mathrm{Hg})$ could inhibit 
further shoot and root development of the ten-day-old rice seedlings and induce transgenerational changes in their DNA methylation pattern at specific loci [41]. Rice plants were treated with two different concentrations of $\mathrm{Cd}, \mathrm{Cr}, \mathrm{Cu}$, or $\mathrm{Hg}$ to determine dose-dependent responses to these heavy metals. As expected, more hypomethylations were observed at specific-loci on the higher doses of $\mathrm{Cd}, \mathrm{Cr}$, and $\mathrm{Cu}$ but no change in DNA methylation pattern was witnessed upon $\mathrm{Hg}$ treatment. Remarkably, the progeny of the stressed plants exhibited enhanced tolerance to the same stress their progenitors experienced and showed the transgenerational inheritance of changes in the DNA methylation patterns [41]. The aim of this study was to address whether locusspecific changes in gene expression also take place in response to the heavy metal stress and whether different classes of genes have common or specific responses to heavy metal stress.

\section{Results}

Heavy metal stress induced locus-specific gene

expression changes in the $S_{0}$ plants

We previously showed that heavy metals elicit epigenetic changes in DNA methylation patterns of specific loci and in a transgenerational manner [41]. In the present study, we addressed whether locus-specific changes in gene expression also take place in response to the heavy metal stress and whether different classes of genes have common or specific responses to the heavy metal stress. To test this possibility, we assessed the expression of 18 randomly-distributed and functionally diverse genes by reverse transcription (RT)-PCR in the heavy-metal stressed rice seedlings (Fig. 1). Out of these 18 genes, two (Tos17 and Osr42) were formerly tested by us to respond epigenetically to the heavy metal stress, seven (Homeobox gene, DNA-binding protein, Elongation factor, HSP70, SNF-FZ14, S3, and YF25) were randomly distributed cellular genes, and nine genes (OsHMA1-OsHMA9) were known to be heavy metal transporters. This panel of genes allows testing if global or specific transcriptional changes are involved in heavy-metal stress avoidance or mitigation in rice. In the $S_{0}$ generation, plants for expression analysis were selected on the basis of the gel-blot analysis. Specifically, $\mathrm{S}_{0}$ plants that showed the most conspicuous modifications in DNA methylation patterns under $\mathrm{Cu}^{2+}(1000 \mu \mathrm{M}), \mathrm{Cd}^{2+}(1000 \mu \mathrm{M}), \mathrm{Cr}^{3+}$ $(1000 \mu \mathrm{M})$ and $\mathrm{Hg}^{2+}(50 \mu \mathrm{M})$ treatments were selected for the expression analysis [41].

Interestingly, we found two rice TE (transposable element) genes, the Tos17 and Osr42 that showed significantly up-regulated expression under all or three of the four heavy metal treatments (Fig. 1 and Table 1). Specifically, for Tos17, there are two copies in wild-type rice $\mathrm{cv}$. Nipponbare, one located on chromosome 10

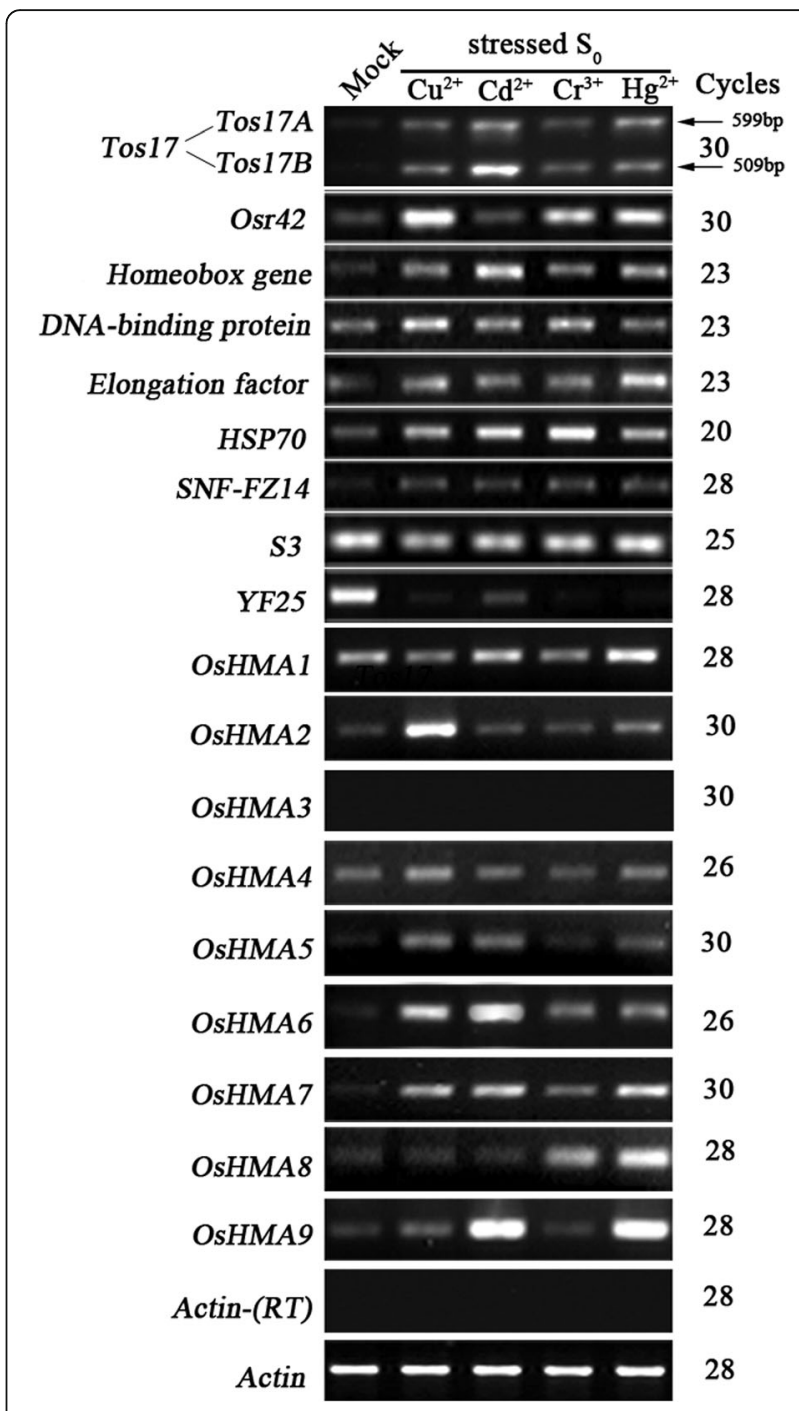

Fig. 1 Alteration in the steady-state transcript abundance determined by semi-quantitative RT-PCR analysis in a set of 18 randomly selected genes, which include two transposable element genes (Tos 17 and Osr42), seven cellular genes (homeobox gene, DNAbinding protein, Elongation factor, HSP70, SNF-FZ14, S3, and YF25), and nine rice Heavy Metal-transporting P-type ATPases (OsHMA1OsHMA9). The results were highly reproducible among the three independent RNA batches, and hence, only one was presented. Gene names are listed to the left and amplification cycles are labeled to the right of the gel. The rice Actin gene (Genbank accession \# X79378) was used as a control for normalization of RNA input. Lack of genomic DNA was validated by the Actin gene on the template without RT

dubbed Tos $17 A$, and the other located on chromosome 7 called Tos $17 B$. The two Tos 17 copies are identical except for a $90 \mathrm{bp}$ insertion in Tos17A [42]. We designed gene-specific primers to study expression changes in the two copies under heavy metal stress. The results showed that the two copies of Tos17 seldom exhibit activation of gene expression under all four (100\%) heavy-metal treatments $\left(S_{0}\right.$ plants), particularly under $C d$ stress. Similarly, 
Table 1 Gene expression changes observed for the 18 functionally diverse random genes in heavy metal treated seedlings of rice cv. Matsumae ( $S_{0}$ generation)

\begin{tabular}{|c|c|c|c|c|c|c|c|}
\hline \multirow[t]{2}{*}{ Gene name } & \multirow[t]{2}{*}{ Genbank acc. ${ }^{a}$} & \multirow[t]{2}{*}{$\mathrm{Chr}^{\mathrm{a}}$} & \multicolumn{5}{|c|}{ Gene expression changes observed in heavy metal treated plants of $S_{0}$ generation ${ }^{b}$} \\
\hline & & & $\overline{\mathrm{Cu}^{2+}\left(1000 \mu \mathrm{m} \cdot \mathrm{L}^{-1}\right)}$ & $\mathrm{Cd}^{2+}\left(1000 \mu \mathrm{m} \cdot \mathrm{L}^{-1}\right)$ & $\mathrm{Cr}^{3+}\left(1000 \mu \mathrm{m} \cdot \mathrm{L}^{-1}\right)$ & $\mathrm{Hg}^{2+}\left(50 \mu \mathrm{m} \cdot \mathrm{L}^{-1}\right)$ & Freq. (\%) \\
\hline \multicolumn{8}{|c|}{ Transposable elements (TEs) } \\
\hline \multirow[t]{2}{*}{ Tos 17} & AC087545 (Tos17A) & 10 & $U$ & $U$ & $U$ & $U$ & 100 \\
\hline & AP008213 $3^{(\text {Tos17B) }}$ & 7 & $U$ & $U$ & $U$ & $U$ & 100 \\
\hline Osr42 & AF458768 & 4 & U & $\mathrm{N}$ & U & U & 75 \\
\hline \multicolumn{8}{|c|}{ Low copy protein-coding genes } \\
\hline Homeobox gene & AB007627 & 2 & $U$ & U & U & $U$ & 100 \\
\hline DNA-binding protein & X88798 & 5 & U & $U$ & U & U & 100 \\
\hline Elongation factor & D12821 & 7 & $U$ & $U$ & U & $U$ & 100 \\
\hline HSP70 & X67711 & 11 & U & $U$ & U & U & 100 \\
\hline SNF-FZ14 & DQ239432 & 7 & $U$ & $U$ & U & U & 100 \\
\hline S3 & AY328087 & 12 & $\mathrm{~N}$ & $\mathrm{~N}$ & $\mathrm{~N}$ & N & 0 \\
\hline YF25 & DQ239435 & 11 & $\mathrm{D}$ & $\mathrm{D}$ & $\mathrm{D}$ & $\mathrm{D}$ & 100 \\
\hline \multicolumn{8}{|c|}{ Rice $P_{1 B}$ subfamily of Heavy Metal-transporting P-type ATPases (HMAs) } \\
\hline OsHMA1 & AP003935 & 6 & $\mathrm{~N}$ & $U$ & $\mathrm{~N}$ & $U$ & 50 \\
\hline OsHMA2 & AP004278 & 6 & U & N & $\mathrm{N}$ & $\mathrm{N}$ & 25 \\
\hline OsHMA3 & AP005246 & 7 & - & - & - & - & - \\
\hline OSHMA4 & AP004184 & 2 & N & N & N & N & 0 \\
\hline OsHMA5 & AL606647 & 4 & U & $U$ & $\mathrm{~N}$ & U & 75 \\
\hline OsHMAG & AP004836 & 2 & U & U & U & U & 100 \\
\hline OsHMA7 & AP004376 & 8 & U & $U$ & $U$ & U & 100 \\
\hline OsHMAB & AC125472 & 3 & $\mathrm{~N}$ & $\mathrm{~N}$ & U & U & 50 \\
\hline \multirow[t]{2}{*}{ OsHMA9 } & AP008212 & 6 & $\mathrm{~N}$ & $U$ & $\mathrm{~N}$ & U & 50 \\
\hline & Total $^{\mathrm{d}}(\%)$ & & 72.2 & 72.2 & 66.7 & 83.3 & \\
\hline
\end{tabular}

Note: ${ }^{a}$ Determined by BlastN searches performed at NCBI

${ }^{b}$ Changes in gene expression pattern were defined as: $\mathrm{N}=$ No change in gene expression; $\mathrm{U}=$ Significantly up-regulated expression; $\mathrm{D}=\mathrm{Significant}$ downregulated expression; and - = No expression

${ }^{c}$ Number of times a gene responded similarly to different heavy metal stresses; represented as percentage in the table

${ }^{d}$ Number of times a heavy metal stress affected different genes in a similar fashion; represented as percentage in the table. For calculations the two copies of the Tos 17 were treated separately

Osr42 showed a significantly up-regulated expression under three $(\mathrm{Cu}, \mathrm{Cr}$, and $\mathrm{Hg})$ of the four $(75 \%)$ heavy metal treatments. The two TE genes exhibited contrasting expression patterns in Cd-treated plants, while Tos17 showed the most conspicuous activation of gene expression, Osr42 exhibited no change in expression.

In addition, among seven low-copy cellular genes (Homeobox gene, DNA-binding protein, Elongation factor, HSP70, SNF-FZ14, S3, and YF25), five of the genes (Homeobox gene, DNA-binding protein, Elongation factor, HSP70, and SNF-FZ14) showed transcriptional upregulation in all (100\%) heavy metal treated plants (Fig. 1 and Table 1). Whereas, YF25 showed significant downregulation under $\mathrm{Cd}$ treatment to complete suppression under other heavy metal treatments $(\mathrm{Cu}, \mathrm{Cr}$, and $\mathrm{Hg})$, and $S 3$ exhibited no change in expression under any of the tested heavy metal treatments.
We also tested the nine rice HMAs (OsHMA1OsHMA9) and found that 7 HMAs showed significant up-regulation under at least one of the four heavy metal treatments (Fig. 1 and Table 1). Specifically, OsHMA1 showed up-regulated expression in $\mathrm{Cd}$ and $\mathrm{Hg}$-treated plants (two of the four heavy metal treatments; $50 \%$ ). Similarly, OsHMA2 showed significantly up-regulated expression in $\mathrm{Cu}$-treated plants (one of the four heavy metal treatments; 25\%). OsHMA5 showed significant transcriptional activation under $\mathrm{Cu}, \mathrm{Cd}$, and $\mathrm{Hg}$ treatments (three of the four heavy metal treatments; 75\%). OsHMA6 and OsHMA7 showed transcriptional activation under all four (100\%) heavy metal treatments. OsHMA8 showed significant transcriptional activation in $\mathrm{Hg}$ and $\mathrm{Cr}$ treated plants (two of the four heavy metal treatments; 50\%), whereas OsHMA9 showed significant transcriptional activation in $\mathrm{Cd}$ and $\mathrm{Hg}$ treated plants 
(two of the four heavy metal treatments; 50\%). OsHMA4 did not show significant transcriptional changes under any of the four heavy metal treatments, and OsHMA3 showed no expression either in plants treated with any of the heavy metals or mock plants.

Taking the results of all four heavy metal treatments together, (i) different genes responded from none $(0 \%)$ to all $(100 \%)$ studied heavy metal treatments by exhibiting alterations in their respective expression patterns. Specifically, 10 of the 18 genes responded to all four heavy metal treatments by transcriptional upregulation. Interestingly, TEs and the low-copy number proteincoding genes showed more transcriptional plasticity than HMAs under heavy metal stress. (ii) With respect to the number of genes that showed transcriptional changes in response to heavy metal stress, $\mathrm{Hg}$ treatment induced changes in expression patterns of the maximum $(83.3 \%)$ number of genes followed by $\mathrm{Cu} / \mathrm{Cd}(72.2 \%)$, and $\mathrm{Cr}$ (66.7\%) treatments. (iii) With respect to type (up- or down-regulation) of the gene expression changes occurring in response to the heavy metal treatment, all genes responded by up-regulation of expression, except YF25 that showed transcriptional downregulation and $S 3$, which exhibited no change in expression pattern (Table 1).

\section{The altered gene expression patterns were transgenerationally inherited, coupled with additional alterations in the $S_{1}$ generation}

To test if the altered gene expression state of the $S_{0}$ plants would be maintained in the next generation, we selfed a single $\mathrm{Hg}^{2+}(50 \mu \mathrm{M})$ treated plant, as this treatment induced gene expression changes in the majority of the studied genes (83.3\%) (Table 1). Later, the leaftissue collected from the $S_{1}$ seedlings growing under optimal conditions was subjected to transcript profiling of 14 genes including two transposable element genes, four cellular genes, and eight OsHMAs. All fourteen genes tested here showed transcriptional changes in $\mathrm{Hg}$ treated $\mathrm{S}_{0}$ plants. We divided the expression state of $\mathrm{S}_{1}$ progeny into three patterns of expression: inheritance of Hg-treated $S_{0}$ pattern, reversion to the mock pattern, and a differential expression pattern. The last category was further divided into two sub-categories: transgenerational memory (further up-regulated expression pattern) and other (cf. Fig. 2 and Table 2).

Specifically, for the two copies of Tos17 (Tos17A and Tos $17 B$ ), the $S_{1}$ progeny either exhibited inheritance of the $\mathrm{S}_{0}$ expression pattern $(62.5 \%$ for Tos $17 A$ and $12.5 \%$ for $T o s 17 B)$ or further up-regulation of it $(37.5 \%$ for Tos $17 A$ and $87.5 \%$ for Tos17B) (Fig. 2 and Table 2). Similarly, for Osr42, $100 \% \mathrm{~S}_{1}$ progeny showed further up-regulation of the $S_{0}$ expression pattern.
Out of four low-copy number protein-coding genes (Fig. 2 and Table 2), for Homeobox gene and HSP70, the majority of $\mathrm{S}_{1}$ progeny ( $75 \%$ for Homeobox gene and $87.5 \%$ for $H S P 70$ ) exhibited stable inheritance of the $S_{0}$ expression pattern, and the remainder $(25 \%$ for Homeobox gene and $12.5 \%$ for HSP70) showed reversal to the mock expression pattern. On the other hand, YF25 which showed significant down-regulation in the $\mathrm{S}_{0}$ generation, exhibited inheritance of the altered expression state, reversal and novel gene expression pattern in the $S_{1}$ progeny at frequencies of 25 , 37.5 , and $37.5 \%$, respectively. For SNF-FZ14, which showed transcriptional activation in $\mathrm{S}_{0}$ generation exhibited further up-regulated expression pattern in the majority $(75 \%)$ of the $S_{1}$ plants and exhibited inheritance of the altered expression state in the remaining $25 \%$ of the progeny.

For the eight OsHMAs tested (Fig. 2 and Table 2), all showed up-regulated expression in $\mathrm{S}_{0}$ plants compared to the mock-treated plants, but differences were found in the $S_{1}$ generation: OsHMA1 showed further up-regulated expression in $100 \%$ progeny. OsHMA2 showed $50 \%$ inheritance of up-regulated expression and reversal to the basal expression state in $50 \%$ of the progeny. OsHMA4 showed the inheritance of the $\mathrm{S}_{0}$ expression state in $37.5 \%$ of the progeny and reversal to the basal expression state in $62.5 \%$ of the progeny. OsHMA5 showed inheritance, reversal and further up-regulated expression patterns in 50, 25, and $25 \%$ of the $\mathrm{S}_{1}$ plants, respectively; OsHMA6, OsHMA7, and OsHMA8 showed inheritance of the altered expression state in $25,12.5$, and $62.5 \%$ of the $S_{1}$ progeny, and further up-regulated expression in 75 , 87.5 , and $37.5 \%$ of the progeny. OsHMA9 showed significantly up-regulated expression in the $S_{0}$ plants, and all $S_{1}$ progeny (100\%) inherited the expression pattern.

In summary, we found that for those genes that showed changes in expression in the $S_{0}$, two major gene expression patterns were manifest in the $S_{1}$ progeny: either inheritance of the $S_{0}$ expression pattern $(41.7 \%)$ or adaptation to a new expression pattern (51.7\%). However, the maintenance of change in gene expression varied among the genes tested. For instance, some genes (Tos17A, Homeobox gene, HSP70, OsHMA2, OsHMA5, OsHMA8 and OsHMA9) exhibited inheritance of the expressed state from $S_{0}$ to $S_{1}$ generations in $\geq 50 \%$ progeny plants, whereas other genes (Tos $17 B$, Osr42, SNF-FZ14, OsHMA1, OsHMA2, OsHMA6, and OsHMA7) showed a further up-regulated expression in $\geq 50 \%$ progeny plants suggesting genetic memory of the altered expression pattern gained in response to the heavy metal treatment that is transmitted to the next generation. 


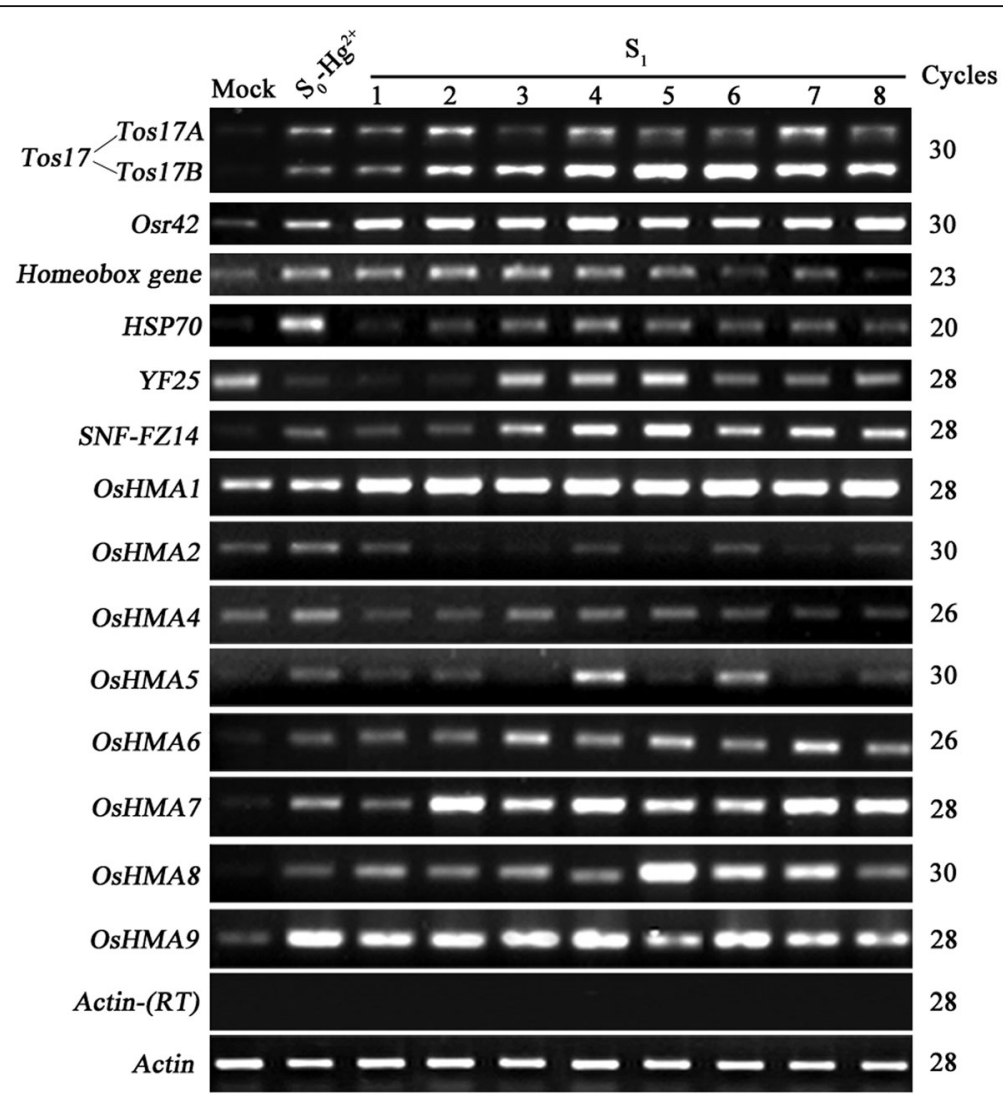

Fig. 2 Transgenerational inheritance of altered expression states of 14 genes in a single $\mathrm{Hg}$-treated $\mathrm{S}_{0}$ rice plant. The mock-treated plant serves as a control, and the $S_{0}$ parental line is the reference for changes in the gene expression in response to Hg-treatment. RNA was isolated from eight $S_{1}$ individual progeny derived from the $S_{0}$ parent. The results were highly reproducible among the three independent RNA batches, and hence, only one was presented. Gene names are listed to the left and amplification cycles are labeled to the right of the gel. Relative band intensities were used to calculate the percent progeny falling in either of the three gene expression categories: i) inheritance of $\mathrm{Hg}$-treated $\mathrm{S}_{0}$ pattern, ii) reversion to the mock pattern, and iii) a differential expression pattern (predominately up-regulated expression compared to the $S_{0}$ progenitor). The rice Actin gene (Genbank accession \# X79378) was used as a control for normalization of RNA input. Lack of genomic DNA was validated by the Actin gene on the template without RT

The altered gene expression states were transgenerationally persistent, coupled with the genetic memory in the $S_{2}$ generation

To further test if the altered expression states are transgenerationally persistent, we selected one $S_{1}$ plant (plant \#3) that exhibited all three expression patterns for several of the tested genes, i.e., inheritance of the $\mathrm{S}_{0}$ expression pattern, reversal to the basal expression pattern and adaption of a new expression pattern, to obtain $\mathrm{S}_{2}$ progeny. To study the expression pattern, we performed the RT-PCR analysis of seven genes (Tos17, SNF-FZ14, OsHMA1, OsHMA2, OsHMA6, OsHMA7, and OsHMA9) in the leaf-tissue of 14 randomly selected $\mathrm{S}_{2}$ individuals grown under optimal conditions. The seven genes selected for RT-PCR analysis showed increased expression in the $S_{0}$ generation and exhibited different expression patterns in the $S_{1}$ generation. Of the seven genes tested, we identified four gene expression patterns in the $S_{2}$ progeny, i.e., the inheritance of the $S_{1}$ expression state, reversion to the $\mathrm{S}_{0}$ expression state, reversion to the mock expression state, and a novel expression pattern (Fig. 3 and Table 3). We observed the majority of $S_{2}$ progeny inherited the expression state of the $S_{1}$ progenitor, $36.6 \%$ progeny showed inheritance of the $S_{1}$ expression state, $22.3 \%$ progeny reverted to the $S_{0}$ expression state, $22.3 \%$ progeny showed reversal to the basal expression state (similar to mock), and the remaining $18.8 \%$ progeny adopted a new expression pattern.

On gene by gene basis, the proportions of $S_{2}$ progeny following one of the four expression patterns (see above) also varied, for instance, in case of Tos17A, OsHMA7, and OsHMA9, $\geq 50 \% \mathrm{~S}_{2}$ progeny exhibited inheritance of the $\mathrm{S}_{1}$ expressed state. For OsHMA1 and OsHMA7, $\geq 50 \% S_{2}$ progeny showed reversal to the expression state of the $\mathrm{S}_{0}$ progenitor. Similarly, for SNF-FZ14 64.3\% $\mathrm{S}_{2}$ progeny showed a reversal to the basal expression state. Whereas, in the case of Tos $17 B$ and OsHMA6 
Table 2 Transgenerational alteration and inheritance of gene expression patterns in 8 randomly chosen $\mathrm{S}_{1}$ plants derived from a $\mathrm{Hg}^{2+}\left(50 \mu \mathrm{m} . \mathrm{L}^{-1}\right)$-treated $\mathrm{S}_{0}$ individual

\begin{tabular}{|c|c|c|c|c|c|c|c|c|c|c|c|c|}
\hline \multirow[t]{2}{*}{ Gene name } & \multicolumn{9}{|c|}{$\begin{array}{l}\text { Alteration of gene expression pattern in the } S_{0} \text { plant and } \\
\text { its } S_{1} \text { progenies }\end{array}$} & \multicolumn{3}{|c|}{ Type and Freq. (\%) of pattern ${ }^{a}$} \\
\hline & $\mathrm{S}_{0}-\mathrm{Hg}^{2+}$ & 1 & 2 & 3 & 4 & 5 & 6 & 7 & 8 & Inherit. of $S_{0}$ pat. & Rev. to mock Pat. & New pat. (Trans. memory/others) \\
\hline Tos17A & U & $\mathrm{i}$ & $+U$ & $\mathrm{i}$ & $+U$ & i & i & $+U$ & i & 62.5 & 0.0 & $37.5(37.5 / 0.0)$ \\
\hline Tos $17 B$ & $U$ & $\mathrm{i}$ & $+U$ & $+U$ & $+U$ & $+U$ & $+U$ & $+U$ & $+U$ & 12.5 & 0.0 & $87.5(87.5 / 0.0)$ \\
\hline Osr42 & $U$ & $+U$ & $+U$ & $+U$ & $+U$ & $+U$ & $+U$ & $+U$ & $+U$ & 0.0 & 0.0 & $100.0(100.0 / 0.0)$ \\
\hline Homeobox gene & $u$ & $\mathrm{i}$ & i & i & i & i & r & i & r & 75.0 & 25.0 & $0.0(0.0 / 0.0)$ \\
\hline HSP70 & $U$ & r & i & i & i & i & i & i & i & 87.5 & 12.5 & $0.0(0.0 / 0.0)$ \\
\hline YF25 & D & $\mathrm{i}$ & i & r & r & r & $-r$ & $-r$ & $-r$ & 25.0 & 37.5 & $37.5(0.0 / 37.5)$ \\
\hline SNF-FZ14 & $U$ & $\mathrm{i}$ & i & $+U$ & $+U$ & $+U$ & $+U$ & $+U$ & $+U$ & 25.0 & 0.0 & $75.0(75.0 / 0.0)$ \\
\hline OsHMA1 & $U$ & $+U$ & $+U$ & $+U$ & $+U$ & $+U$ & $+U$ & $+U$ & $+U$ & 0.0 & 0.0 & $100.0(100.0 / 0.0)$ \\
\hline OSHMA2 & $U$ & i & $D$ & $D$ & i & $D$ & i & $D$ & i & 50.0 & 0.0 & $50.0(0.0 / 50.0)$ \\
\hline OsHMA4 & U & r & r & $\mathrm{i}$ & i & i & r & r & r & 37.5 & 0.0 & $62.5(0.0 / 62.5)$ \\
\hline OSHMA5 & $U$ & i & i & r & $+U$ & i & $+U$ & r & i & 50.0 & 25.0 & $25.0(25.0 / 0.0)$ \\
\hline OsHMAG & $U$ & $\mathrm{i}$ & i & $+U$ & $+U$ & $+U$ & $+U$ & $+U$ & $+U$ & 25.0 & 0.0 & $75.0(75.0 / 0.0)$ \\
\hline OsHMA7 & $U$ & i & $+U$ & $+U$ & $+U$ & $+U$ & $+U$ & $+U$ & $+U$ & 12.5 & 0.0 & $87.5(87.5 / 0.0)$ \\
\hline OsHMA8 & U & i & i & i & i & $+U$ & $+U$ & $+U$ & i & 62.5 & 0.0 & $37.5(37.5 / 0.0)$ \\
\hline OsHMA9 & U & i & i & i & i & i & i & i & i & 100.0 & 0.0 & $0.0(0.0 / 0.0)$ \\
\hline Average Freq. $(\%)^{\mathrm{a}}$ & & & & & & & & & & 41.7 & 6.7 & $41.7 / 10.0$ \\
\hline
\end{tabular}

Explanation of symbols: $\mathrm{U}=$ up-regulated gene expression in the $\mathrm{S}_{0}$ plant;

$+U$ denotes further up-regulated gene expression in the $S_{1}$ progeny plant;

D denotes down-regulated gene expression in the $S_{1}$ progeny plants compared to the mock control

i denotes inheritance of $S_{0}$ expression pattern in the $S_{1}$ progeny;

$r$ denotes reversal to Mock control expression pattern in the $S_{1}$ progeny;

Note: ${ }^{a}$ The average frequency of the specified pattern in $S_{1}$ progeny plants. For calculations the two copies of Tos 17 were treated separately,

${ }^{a}$ Relative band intensities were used to calculate the percent progeny following in either of the three gene expression categories: $\left.\mathrm{i}\right)$ inheritance of $\mathrm{Hg}$ - treated $\mathrm{S}_{0}$ pattern, ii) reversion to the mock pattern, and iii) a differential expression pattern (cf. Fig. 2)

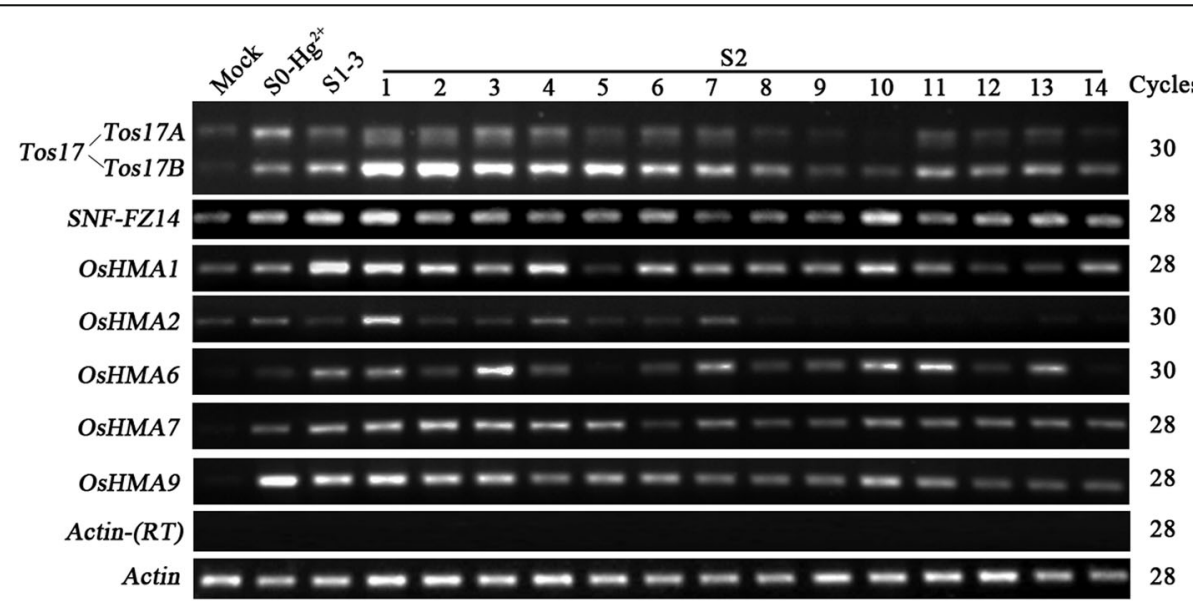

Fig. 3 Transgenerational inheritance of altered expression states of seven genes in a single $S_{1}$ rice plant. As evidence of inheritance of the expression states, the $S_{0}$ and $S_{1}$ plants are used as a reference as well as the mock control (no metal treatment). A total of $14 S_{2}$ individuals were examined to determine the expression of the TOS17A, TOS17B, SNF-FZ14 and five OSHMA transporters in the second generation. Gene names are listed to the left and amplification cycles are labeled to the right of the gel. Relative band intensities were used to calculate the percent progeny falling in either of the four gene expression categories: i) inheritance of the $S_{1}$ expression state, ii) reversion to the $S_{0}$ expression state, iii) reversion to the mock expression state, and iv) a novel expression pattern. The rice Actin gene (Genbank accession \# X79378) was used as a control for normalization of RNA input. Lack of genomic DNA was validated by the Actin gene on the template without RT 
Table 3 Transgenerational alteration and inheritance of gene expression patterns in the 14 randomly chosen $S_{2}$ plants derived from one $S_{1}$ individual \#3 $\left(S_{1}-3\right)$, which was derived from a single $\mathrm{Hg}^{2+}(50 \mu \mathrm{m})$-treated $\mathrm{S}_{0}$ individual

\begin{tabular}{|c|c|c|c|c|c|c|c|c|c|c|c|c|c|c|c|c|c|c|c|c|}
\hline \multirow{2}{*}{$\begin{array}{l}\text { Gene } \\
\text { name }\end{array}$} & \multirow[b]{2}{*}{$\begin{array}{l}\mathrm{S}_{0^{-}} \\
\mathrm{Hg}^{2+}\end{array}$} & \multirow[b]{2}{*}{$\begin{array}{l}\mathrm{S}_{1-} \\
3\end{array}$} & \multicolumn{14}{|c|}{ Gene expression patterns in the $S_{2}$ progeny } & \multicolumn{4}{|c|}{ Frequency $(\%)^{b}$} \\
\hline & & & 1 & 2 & 3 & 4 & 5 & 6 & 7 & 8 & 9 & 10 & 11 & 12 & 13 & 14 & $\begin{array}{l}\text { Inherit. } \\
\text { of } S_{1} \\
\text { pat. }\end{array}$ & $\begin{array}{l}\text { Rev. to } \\
S_{0} \text { pat. }\end{array}$ & $\begin{array}{l}\text { Rev. to } \\
\text { mock } \\
\text { pat. }\end{array}$ & $\begin{array}{l}\text { New pat. (Trans. } \\
\text { Memory/others) }\end{array}$ \\
\hline Tos17A & U & $U$ & $U$ & U & U & U & r & U & U & r & r & r & U & r & U & r & 57.1 & 0.0 & 42.9 & $0.0(0.0 / 0.0 /)$ \\
\hline Tos17B & $U$ & $+U$ & $++U$ & $++U$ & $++U$ & $++U$ & $++U$ & $++U$ & $++U$ & $+U$ & U & $U$ & $+U$ & $+U$ & $+U$ & $+U$ & 35.7 & 0.0 & 14.3 & $50.0(50.0 / 0.0)$ \\
\hline SNF-FZ14 & $U$ & $+U$ & $++U$ & $U$ & $U$ & $U$ & U & $U$ & r & r & r & $++U$ & $U$ & U & $U$ & $U$ & 0.0 & 21.4 & 64.3 & $14.3(14.3 / 0.0)$ \\
\hline OsHMA1 & $U$ & $+U$ & $+U$ & $+U$ & $U$ & $+U$ & $r$ & U & U & $U$ & $U$ & $+U$ & $U$ & r & $r$ & $U$ & 28.6 & 50.0 & 21.4 & $0.0(0.0 / 0.0)$ \\
\hline OsHMA2 & U & $D$ & $+U$ & r & $r$ & $U$ & r & r & U & $-D$ & $-D$ & $-D$ & $-D$ & $-D$ & $-D$ & $-D$ & 0.0 & 14.3 & 28.6 & $57.1(0.0 / 57.1)$ \\
\hline OsHMA6 & U & $+U$ & $+U$ & $U$ & $++U$ & $U$ & $++U$ & U & $+U$ & U & $U$ & $++U$ & $++U$ & U & $+U$ & r & 21.4 & 42.9 & 7.1 & $28.6(28.6 / 0.0)$ \\
\hline OsHMA7 & U & $+U$ & $+U$ & $+U$ & $+U$ & $+U$ & $+U$ & U & $+U$ & U & U & $+U$ & U & U & U & U & 50.0 & 50.0 & 0.0 & $0.0(0.0 / 0.0)$ \\
\hline OsHMA9 & $U$ & U & $U$ & U & U & $U$ & U & U & U & U & $U$ & U & $U$ & U & U & U & 100.0 & 0.0 & 0.0 & $0.0(0.0 / 0.0)$ \\
\hline $\begin{array}{l}\text { Average } \\
\text { Freq. } \\
(\%)^{a}\end{array}$ & & & & & & & & & & & & & & & & & 36.6 & 22.3 & 22.3 & $18.8(11.6 / 7.2)$ \\
\hline
\end{tabular}

Explanation of symbols: $\mathrm{U}$ denotes up-regulated gene expression in the $\mathrm{S}_{0}$ plant, and kept the trend in $\mathrm{S}_{1}-3$ and $\mathrm{S}_{2}$ individuals;

$+U$ denotes further up-regulated gene expression in the $S_{1}-3$ and kept the trend in $S_{2}$ individuals;

$++U$ denotes further up-regulated gene expression in $S_{2}$ individuals compared to their $S_{1}$ progenitor;

$D=$ denotes down-regulated gene expression in the $S_{1}-3$ compared to the Mock control;

-D denotes further down-regulated gene expression in $S_{2}$ individuals compared to their $S_{1}$ progenitor;

$r$ denotes reversal to Mock control expression pattern in the $S_{2}$ progeny;

Note: ${ }^{a}$ The average frequency of the specified pattern in $S_{2}$ progeny plants. For calculations the two copies of Tos 17 were treated separately,

${ }^{b}$ Relative band intensities were used to calculate the percent progeny following in either of the four gene expression categories (cf. Fig. 3 )

respectively 50 and $28.6 \% \mathrm{~S}_{2}$ progeny showed a further up-regulation of the $S_{1}$ expression pattern.

Collectively, these results suggested that the altered gene expression states induced by heavy metal stress are heritable (11.6\%; Table 3), and hence indicates transgenerational memory is involved. Additionally, the progeny also appears to maintain the upward trend of induced expression in response to heavy metal stress.

\section{DNA methylation changes of Tos17 and its transgenerational effect}

To further explore whether DNA methylation was also altered due to heavy metal stress and to explain its inheritance across generations, we chose $\mathrm{Hg}$-treated $\mathrm{S}_{0}$ plants, one $S_{1}$ individual (\#3) and one $S_{2}$ individual (\#11) to investigate the methylation state and its transmission. We chose Tos17 as a representative gene to test because both copies of Tos 17 showed induced expression in the $\mathrm{S}_{0}$ and the progeny kept the trend through two successive generations. We analyzed cytosine methylation patterns of Tos $17 A$ and $T o s 17 B$ by bisulfite sequencing (Fig. 4). Specifically, we inspected the $5^{\prime}$ - LTR and its immediate upstream and downstream regions as well as the 3 '-LTR and its immediate upstream and downstream regions for Tos $17 A$ and Tos $17 B$ located on chromosomes 7 and 10, respectively. The results of bisulfite sequencing are presented in Fig. 4, and some salient observations are described: (i) The region immediately upstream of
5 '-LTR in Tos17A showed no change in DNA methylation in the $S_{0}$ plants and the $S_{1} / S_{2}$ progeny; the LTR region was slightly methylated at CG and CNG regions in the mock-treated plants and showed CG hypermethylation in $\mathrm{S}_{0}$ plants, further hypermethylation in $\mathrm{S}_{1}$ progeny and inheritance of methylation state in $\mathrm{S}_{2}$ plants. (ii) The 3 '-LTR and its flanking regions in Tos17A showed CG hypermethylation and partial methylation for CNG and $\mathrm{CNN}$ sequences in the mock plants. However, the CG methylation pattern remained unchanged in the $S_{0}, S_{1}$, and $\mathrm{S}_{2}$ plants. A slight loss of CNG methylation was observed in the body and LTR regions in $\mathrm{S}_{0}$ plants, but increased methylation levels were observed in the $S_{1}$ progeny. In the $S_{2}$ progeny, a slight decrease in methylation pattern in the body region and hypermethylation in the LTR region was observed (Fig. 4a). (iii) The flanking region upstream of the $5^{\prime}$-LTR of Tos17B was unmethylated in the mock plants and showed slight de novo methylation in CNG sequences in the $S_{0}$ plants, a pattern which disappeared in the $S_{1}$ progeny. In contrast, the $5^{\prime}$-LTR and the downstream body regions of Tos $17 B$ showed heavy methylation in CG sequences, and slight to moderate increases in $\mathrm{CNN}$ and $\mathrm{CNG}$ methylation compared to the mock control. A decrease of CG methylation was observed in the $S_{1}$, as well as a decrease in CNG methylation in both $S_{0}$ and $S_{1}$, but an increase in CNG methylation was found in the $S_{2}$ progeny (Fig. $4 \mathrm{~b}$ ). Taken together, the results of bisulfite sequencing at Tos $17 A$ and Tos $17 B$ 


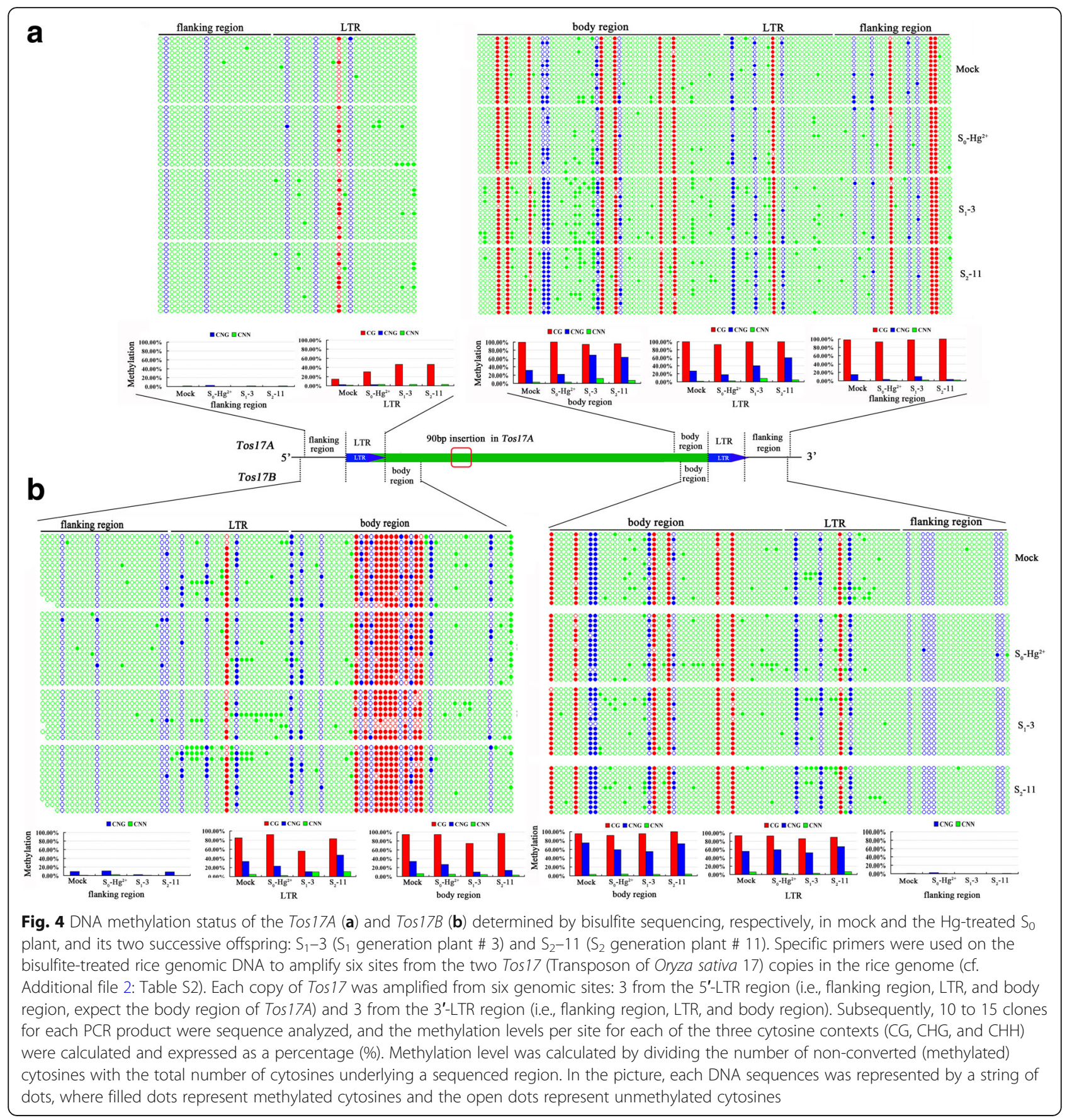

confirmed that DNA methylation changes occur in response to the heavy metal treatment and also showed transgenerational inheritance. Furthermore, the major pattern of DNA methylation changes is CNG hypomethylation in the $S_{0}$, which showed different transgenerational effects in either the $3{ }^{\prime}$-region of Tos $17 A$ or $5^{\prime}$-region of Tos $17 B$.

The gene expression and DNA methylation of two copies of Tos17 changed under heavy metal stress and showed transgenerational memory of the stress. In addition, under certain circumstances, some of the epigenetically silenced TEs are known to become activated and then transpose. TE activity is often causally linked to the compromised repressive epigenetic state in which cytosine DNA methylation is a critical component. We, therefore, analyzed Tos 17 mobility in the $\mathrm{S}_{0}, \mathrm{~S}_{1}$, and $\mathrm{S}_{2}$ generations by Southern blotting. The results showed that Tos 17 stayed inactive, which is evident from the consistent copy number maintained in individuals from the $S_{0}, S_{1}$, and $S_{2}$ generations (Fig. 5). 


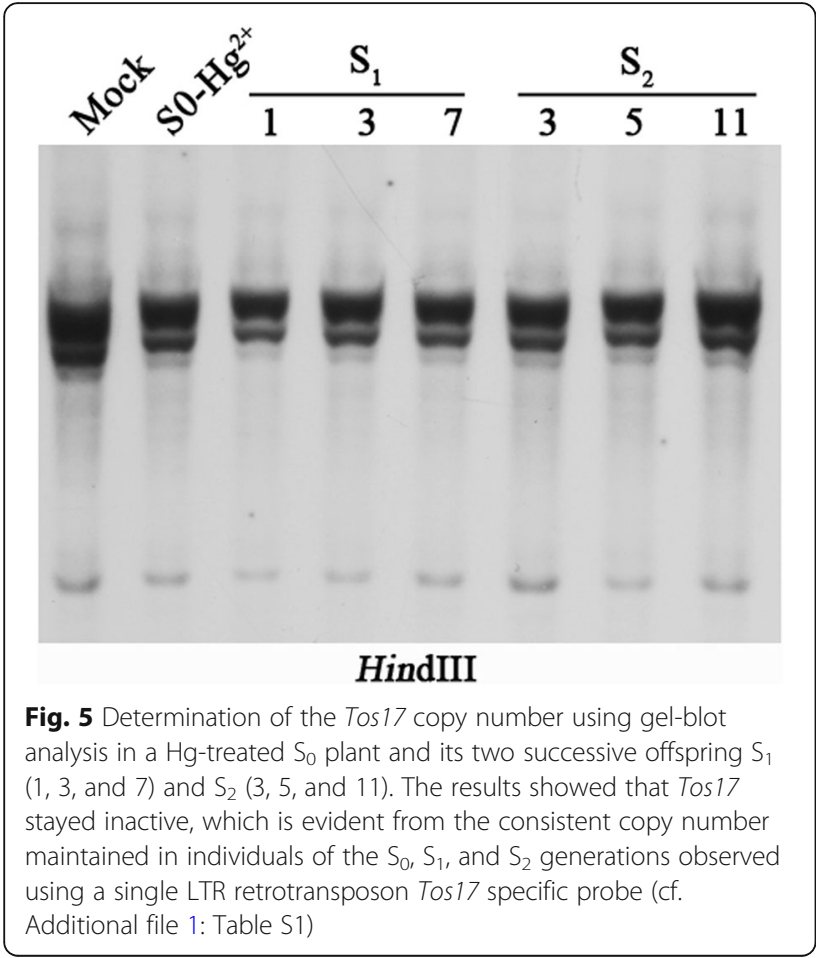

\section{Discussion and conclusions}

In this study, locus-specific gene expression changes and the transgenerational effect of heavy metal stress in rice were analyzed. For this purpose, we chose two retrotransposons, seven protein-coding genes, and nine rice $\mathrm{OsH}$ $M A s$, most of them except seven OsHMAs were analyzed in a previous study of the transgenerational inheritance of modified DNA methylation patterns in response to heavy metal stress [41]. In the present study, we addressed whether the altered expression state of the target genes in response to heavy metal stress is transgenerationally inherited and whether different kinds of genes have common or specific responses to the same heavy metal stress. Based on our previous findings, we chose a single dose of each heavy metal that induced maximum DNA methylation changes [41], and also included a lower dose of heavy metal to study its effect on the transcription and methylation states. The results showed that 16 of 18 genes exhibited up-regulated expression upon treatment with at least one heavy metal (Fig. 1), indicating that a common response might exist for most genes upon heavy metal stress. Our previous data showed that Tos 17 and Osr42 exhibit up-regulated expression in response to nitric oxide (NO) treatment in rice [43]. It indicates that these two retrotransposons exhibit transcriptional plasticity to cope with stress. For Tos17, we examined the transcriptional response of the two genomic copies, and both of them showed activation in response to the heavy metal treatment (Fig. 1). It is the first time that the transcriptional activation of both copies of Tos 17 was demonstrated in response to abiotic stress.

All OsHMAs except OsHMA3 showed significantly upregulated expression in response to at least one kind of heavy metal treatment, which suggested that these might all be involved in the heavy metal transport. Previous reports suggested OsHMA1 to be exclusively involve in $\mathrm{Zn}$ transport [26], however, in the present study, it showed significantly up-regulated expression in $\mathrm{Hg}$ treated rice plants, implicating that it might be also involved in transporting Hg. Similarly, OsHMA2 was formerly reported to be expressed in the root maturation zone and to function in the root-shoot translocation of $\mathrm{Zn}$ and Cadmium (Cd) $[28,44]$. In the present study, OsHMA2 showed transcriptional activation in $\mathrm{Cu}$ treated rice plants, suggesting its potential role in copper $(\mathrm{Cu})$ transport. OsHMA3 was localized to tonoplast in the root cells and was found to be responsible for Cd sequestration in vacuoles $[29,30,45]$. In the present study, OsHMA3 showed no expression in rice shoots or induction after $\mathrm{Cu}, \mathrm{Cd}, \mathrm{Cr}$ or $\mathrm{Hg}$ treatment, which is consistent with a recent report that it was not induced in roots and shoots of Cr-treated rice plants [46]. However, overexpression of OsHMA3 was shown to enhance Cd tolerance in rice [47], and a loss-of-function allele was shown to accumulate $\mathrm{Cd}$ in grains and shoots [48]. Interestingly, it was recently shown that OsHMA3 driven under the control of the OsHMA2 promoter was successful at reducing $\mathrm{Cd}$ accumulation in rice grains [28]. OsHMA4 is localized to the vacuolar membrane, and its expression was shown to be induced by long-term $\mathrm{Cu}$ treatment and suppressed by $\mathrm{Cu}$ deficiency [31] suggesting its role in $\mathrm{Cu}$ sequestration in vacuoles and consequently $\mathrm{Cu}$ tolerance. In the present study, OsHMA4 was only slightly induced by $\mathrm{Cu}$ treatment, which is in conformity with the previous reports where OsHMA4 was only shown to be induced by long-term $\mathrm{Cu}$ treatment [27, 31]. OsHMA5 was mainly expressed in the roots at the vegetative stage, and its expression was shown to be upregulated by the excess of $\mathrm{Cu}$ and other metals such as $\mathrm{Zn}, \mathrm{Fe}$, and $\mathrm{Mn}$ [32]. Here, we report that OsHMA5 is not expressed in the shoots of mock-treated plants, but is induced in the presence of $\mathrm{Cu}$, which is consistent with a previous study [32]. Additionally, we noticed that OsHMA5 exhibits induced expression in the presence of $\mathrm{Cd}$ and $\mathrm{Hg}$ as well. There are few reports on the function of OsHMA6, OsHMA7, and OsHMA8. These genes are largely silent in the shoots and only exhibited transcriptional activation under heavy metal stress. Although detailed functions are not known for these genes, our data suggest they may also play a role in heavy metal detoxification. Previous reports showed that OsHMA9 is mainly expressed in vascular tissues and its expression could be induced by high concentrations of $\mathrm{Cu}, \mathrm{Zn}$ or 
$\mathrm{Cd}$ [27]. In the present study, OsHMA9 showed significant transcriptional activation in $\mathrm{Cd}$ and $\mathrm{Hg}$ treated plants, and a slight up-regulation in $\mathrm{Cu}$ treated plants. Our data support an additional role for OsHMA9 in Hg efflux.

To confirm and extend our findings, we tested whether the altered gene expression state of $S_{0}$ plants was transgenerationally inherited by the $S_{1}$ and $S_{2}$ progeny. We reported an average inheritance rate of $41.7 \%$ in the $S_{1}$ and $36.6 \%$ in the $S_{2}$ (Figs. 2, 3 and Tables 2, 3). However, the rate of inheritance varied depending on gene in question. A majority of the genes tested showed up-regulated expression in the $S_{1}(41.7 \%)$ and about $11.6 \%$ maintained the trend of up-regulated expression and exhibited further up-regulation in the $\mathrm{S}_{2}$. It indicates that the progeny maintained a memory of the altered expression state of the progenitors even after removal of the heavy metal. Recently, some studies showed a clear connection between the ethylene signaling and response to heavy metal stress in diverse plant species [49-51]. We have not evaluated this aspect in the present study, but believe it is worthy of checking the transcriptional pattern of ethylene biosynthesis and signaling genes in heavy metal treated plants and study the transgenerational inheritance of the expression pattern.

The traditional concept of epigenetics refers to heritable changes in gene expression without an accompanying change in the DNA sequence. Recent research advocates inclusion of the 'memory concept' in the formal definition of epigenetics, as even after the disappearance of the initial stress signal, the DNA and/or chromatin modifications are transmitted to maintain the altered transcriptional state from one generation to another $[52,53]$. Several studies showed that epigenome is remodeled in plants upon exposure to diverse stresses and DNA methylation pattern is most likely to respond [54-59]. It has been proposed that the DNA methylation state is only partially transmitted to the immediate offspring, as part of it resets during sexual reproduction, which in turn limits the transmission of the acquired epigenetic alterations from parents to offspring [60, 61]. However, our previous research demonstrated that the heavy metal-induced DNA methylation changes in rice are inheritable for at least two successive generations [41]. Here, we monitored the DNA methylation changes under heavy-metal stress in two copies of Tos 17 and studied the transgenerational inheritance of epigenetic changes by bisulfite sequencing (Fig. 4). We observed that the major DNA methylation change in Tos17 is CNG hypomethylation, which showed variable inheritance patterns in the $3^{\prime}$ - and $5^{\prime}$-regions of the two genomic copies of Tos17 (Tos17A and Tos17B). These observations conform with our previous findings where CNG hypomethylation was most prevalent in response to heavy metal stress and showed at least partial inheritance of the epigenetic changes [41, 43]. DNA methylation changes are associated with changes in gene expression. For instance, A. thaliana mutants defective in DNA methylation showed that regulation of phosphate-starvation-responsive genes requires changes in the DNA methylation pattern [59]. Thus, we set out to find the relationship between DNA methylation and gene expression. Our data suggest that there is no direct correlation between the methylation status and gene expression for Tos17. Moreover, Tos17 stayed silent over three generations, which indicates that the methylation changes in Tos17 are not sufficient for its activation followed by transposition. However, it is unclear whether the heritable change in gene expression is related to methylation changes as there can be locus-specific changes in methylation. Moreover, our study was limited to Tos17A and Tos17B.

Interestingly, recent research has proposed a key role for dynamic changes in chromatin substructure in transgenerational memory of gene expression changes in response to various stresses [62-64]. In line with this research, maize-researchers showed that stress-induced changes in chromatin structure activate transposable elements, and new transposition events contribute to altered phenotypes observed in the progeny [65]. Several studies indicated that DNA methylation and small interfering (si) RNAs might play a role in transgenerational epigenetic memory, i.e., modification in gene expression patterns that are transmittable across generations via the germline [37, 66-69]. Therefore, we expect a role for siRNA in the observed transgenerational memory of heavy-metal induced transcriptional and epigenetic changes in the rice genome. However, as noted by Probst and Mittelsten [63], while the concept of transgenerational memory is attractive, it is difficult to determine the actual mechanism contributing to it and the number of generations in which it persists.

\section{Methods \\ Plant material}

O. sativa L. ssp. japonica, cv. Matsumae, a cultivated rice, used in the present study was initially obtained from Japan and has since been propagated for more than twenty generations in our laboratory. For the experiments elaborated here, seeds were thoroughly washed with distilled water and germinated in the dark at $28{ }^{\circ} \mathrm{C}$ in Petri dishes containing distilled water. After two days incubation, seedlings were transferred to a greenhouse maintained at $26^{\circ} \mathrm{C}$ under a $12 \mathrm{~h}$ photoperiod.

\section{Heavy metal treatment}

The ten-day-old, seedlings were subjected to different heavy metal treatments: $\mathrm{Cu}^{2+}(50 \mu \mathrm{M}$ or $1000 \mu \mathrm{M}$ 
$\left.\mathrm{CuSO}_{4}\right), \mathrm{Cd}^{2+}(50 \mu \mathrm{M}$ or $1000 \mu \mathrm{M} \mathrm{CdCl}), \mathrm{Cr}^{3+}(50 \mu \mathrm{M}$ or $\left.1000 \mu \mathrm{M} \mathrm{CrCl}_{3}\right)$ or $\mathrm{Hg}^{2+}\left(50 \mu \mathrm{M}\right.$ or $\left.1000 \mu \mathrm{M} \mathrm{HgCl}_{2}\right)$ in Hoagland nutrient solution for a week. As several microelements in Hoagland nutrient solution are either used as sulfates or chlorides, and the $\mathrm{pH}$ of the solution is also adjusted using sulfuric acid, so we made no attempts to balance the sulfate and chloride ions in the Hoagland solution. Additionally, the treatments are similar to the one reported in our previous work [41]. Mock controls were grown in parallel in the Hoagland nutrient solution. After treatment, seedlings were transplanted to the field. Leaf samples were harvested at different time points in liquid nitrogen and stored at $-80^{\circ} \mathrm{C}$ until used. The plants were marked "stressed S0". Panicles of several selected stressed and mock plants were bagged for self-pollination and seeds were collected to produce the next generation of plants, which were labeled as S1. In a similar way, S2 generation plants were produced, and the seeds were harvested.

\section{Reverse-transcription PCR (RT-PCR) analysis}

RT-PCR was performed essentially as reported in Liu et al. [70]. In brief, total RNA was isolated from expanded young leaves using Trizol reagent (Invitrogen) following the manufacturer's instructions. RNA was converted to cDNA using Super ScriptTM RNase H reverse transcriptase kit (Invitrogen), and subjected to RT-PCR analysis using gene-specific primers (Additional file 1: Table S1). The rice Actin gene (Genbank accession \# X79378) was used as the control for normalization of RNA input. Gene-specific primers were designed using Primer 3 (http://bioinfo.ut.ee/primer3/) and are listed in Additional file 1: Table S1. Different cycle numbers were used for different genes to ensure amplifications stay within the linear range for each gene. For $\mathrm{S}_{0}$ samples, we pooled seedings and used three technical replications to check the gene expression changes. Whereas, for the $S_{1}$ and $S_{2}$ individuals, three batches of independently prepared total RNAs were used as technical replications. The amplified products were visualized via agarose gel electrophoresis and ethidium bromide staining.

\section{Bisulfite sequencing of the Tos 17 loci}

Genomic DNA was extracted from fully expended rice leaves and was given a bisulfite treatment [71]. Briefly, an EZ DNA Methylation-Gold Kit from Zymo Research was used to treat $5 \mu \mathrm{g}$ of genomic DNA. The PCR primers, which were used to amplify bisulfite-converted genomic DNA for the two copies of the Tos17 (Transposon of Oryza sativa 17), are listed in Additional file 2: Table S2. From 10 to 15 clones for each sample were sequence analyzed. The methylation level was expressed as the percentage (\%) per site for each of the three cytosine contexts (CG, $\mathrm{CHG}$, and $\mathrm{CHH}$ ). Methylation level was calculated by dividing the number of non-converted (methylated) cytosines with the total number of cytosines underlying a sequenced region. The sequences were analyzed by the Kismeth program (http://katahdin. mssm.edu/kismeth/revpage.pl), and the results were presented as histograms.

\section{Southern blotting}

Genomic DNA was isolated from fully expanded leaves of heavy metal-stressed and mock control rice plants by a modified CTAB method [72] and purified by phenol extraction. For the transposon activity analysis, $5 \mu \mathrm{g}$ of genomic DNA was digested with Hind III (NEB) and resolved on $1 \%$ agarose gel. Subsequently, DNA was transferred to Hybond $\mathrm{N}+$ nylon membranes (Amersham Pharmacia Biotech, Piscataway, New Jersey) via alkaline transfer, as recommended by the manufacturer. Only one Tos 17 copy was used as a probe in the present study (see Additional file 1: Table S1). For probe preparation, the Tos17 fragments were amplified via PCR at annealing temperature $59^{\circ} \mathrm{C}$. The authenticity of the PCR products was confirmed by DNA sequencing. The fragments were gel-purified and labeled with fluorescein-11dUTP using the Gene Images random prime-labeling module from Amersham Pharmacia Biotech. Hybridization signal was detected by the Gene Images $\mathrm{CD}^{2+}$ P-Star detection module (Amersham Pharmacia Biotech) after two stringent washes with $0.2 \times$ SSC and $0.1 \%$ SDS for 50 min each. Subsequently, the membrane was exposed to X-ray film.

\section{Additional files}

Additional file 1: Table S1. List of gene-specific primers used for RT-PCR analysis and amplification of probe used for Southern blotting. (DOC $50 \mathrm{~kb}$ )

Additional file 2: Table S2. List of primers used for bisulfite sequencing of Tos17. (DOC $39 \mathrm{~kb}$ )

\section{Abbreviations \\ Cd: Cadmium; Co: Cobalt; Cr: Chromium; CTAB: Cetyltrimethylammonium bromide; Cu: Copper; Hg: Mercury; HMA: Heavy Metal-transporting P-type ATPases; NO: Nitric oxide; Pb: Lead; RT-PCR: Reverse transcription-polymerase chain reaction; SDS: Sodium dodecyl sulfate; SSC: Saline sodium citrate; TE: Transposable element; Zn: Zinc}

\section{Acknowledgments}

We greatly thank for the support of "National college student life science competition committee", as four college students (YCL, WJM, LCH and ZR) contributing to this study.

\section{Authors' contributions}

CWX, XL, MYL performed RT-PCR analysis and they contributed equally to this work; ZYH performed bisulfite sequencing; ZYH, YCL, WJM, LCH, ZR are responsible for the heavy metal treatment of rice plants; $Z T T, L X Y, J L L, W N N$, $\mathrm{MJ}$ are responsible for rice filed propagation; LB participated in the design, SR and OXF conceived the study, participated in the design and wrote the manuscript with help from KAS. All authors have read and approved the final manuscript. 


\section{Funding}

This work was supported by National Natural Science Foundation of China (No. 31200198 and No. 31400256), National Students' platform for innovation and entrepreneurship training program (No.201810200055), National college student life science competition committee, and NIFA Hatch/Multi-state grant (S009) to SR. The funders had no role in study design, data collection and analysis, decision to publish, or preparation of the manuscript.

\section{Availability of data and materials}

All data generated or analyzed during this study are included in this published article [and its supplementary information files].

\section{Ethics approval and consent to participate}

Not applicable.

\section{Consent for publication}

Not applicable.

\section{Competing interests}

Author Bao Liu is a Section Editor of BMC Plant Biology and no other authors have competing interests.

\section{Author details}

${ }^{1}$ Key Laboratory of Molecular Epigenetics of MOE and Institute of Genetics \& Cytology, Northeast Normal University, Changchun 130024, China. ${ }^{2}$ Jilin Academy of Agricultural Sciences, Changchun 130033, China. ${ }^{3} \mathrm{Jilin}$ Agriculture University, Changchun 130000, China. ${ }^{4}$ Department of Crop and Soil Sciences, Washington State University, Pullman, WA 99164, USA. ${ }^{5}$ Department of Plant and Environmental Sciences, Clemson University, Pee Dee Research and Education Center, Florence, SC 29506, USA.

\section{Received: 31 October 2018 Accepted: 13 June 2019}

\section{Published online: 27 June 2019}

\section{References}

1. Bermudez GMA, Jasan R, Pla R, Pignata ML. Heavy metals and trace elements in atmospheric fallout: their relationship with topsoil and wheat element composition. J Hazard Mater. 2012;213:447-56.

2. Kaplan $\mathrm{O}$, Ince M, Yaman M. Sequential extraction of cadmium in different soil phases and plant parts from a former industrialized area. Environ Chem Lett. 2011;9:397-404.

3. Shanker AK, Djanaguiraman M, Venkateswarlu B. Chromium interactions in plants: current status and future strategies. Metallomics. 2009;1:375-83.

4. Mayor DJ, Gray NB, Elver-Evans J, Midwood AJ, Thornton B. Metalmacrofauna interactions determine microbial community structure and function in copper contaminated sediments. PLoS One. 2013:8:64-94.

5. Guzel S, Terzi R. Exogenous hydrogen peroxide increases dry matter production, mineral content and level of osmotic solutes in young maize leaves and alleviates deleterious effects of copper stress. Bot Stud. 2013;54 26.

6. Kabata-Pendias A. Trace Elements in Soil and Plants. fourth ed. CRC Press, FL, U S A. 2011. P.520.

7. Kazakou E, Dimitrakopoulos PG, Baker AJM, Reeves RD, Troumbis AY. Hypotheses, mechanisms and trade-offs of tolerance and adaptation to serpentine soils: from species to ecosystem level. Biol Rev. 2008:83:495-508.

8. Yang Z, Wu YR, Ling HQ, Clu CC. OsMT1a, a type 1 metallothionein, plays the pivotal role in zinc homeostasis and drought tolerance in rice. Plant Mol Biol. 2009;70:219-29.

9. Clemens S. Molecular mechanisms of plant metal tolerance and homeostasis. Planta. 2001;212:475-86.

10. Mganga N, Manoko MLK, Rulangaranga ZK. Classification of plants according to their heavy metal content around North Mara gold mine, Tanzania: implication for phytoremediation. Tanzania J Sci. 2011;37:109-19.

11. Sytar O, Kumar A, Latowski D, Kuzynska P, Strzalka K, Prasad MNK. Heavy metal induced oxidative damage, defense reactions, and detoxification mechanisms in plants. Acta Physiol Plant. 2013:35:985-99.

12. Song WY, Mendoza-Cozatl DG, Lee Y. Phytochelatin-metal (loid) transport into vacuoles shows different substrate preferences in barley and Arabidopsis. Plant Cell Enviro. 2014;37:1192-201.
13. Rascio N, Navari-Izzo F. Heavy metal hyperaccumulating plants: How and why do they do it? And what makes them so interesting? Plant Sci. 2011; 180:169-81.

14. Colangelo EP, Guerinot ML. Put the metal to the petal: metal uptake and transport throughout plants. Curr Opin Plant Biol. 2006;9:322-30.

15. Kraemer U, Talke IN, Hanikenne M. Transition metal transport. FEBS Lett. 2007; $581: 2263-72$

16. Axelsen $\mathrm{KB}$, Palmgren MG. Inventory of the superfamily of P-type ion pumps in Arabidopsis. Plant Physiol. 2001;126:696-706.

17. Williams LE, Mills RF. P1B-ATPases-an ancient family of transition metal pumps with diverse functions in plants. Trends Plant Sci. 2005;10:491-502.

18. Takahashi R, Ishimaru Y, Shimo H, Ogo Y, Senoura T, Nishizawa NK, et al. The OsHMA2 transporter is involved in root-to-shoot translocation of $\mathrm{Zn}$ and $\mathrm{cd}$ in rice. Plant Cell Environ. 2012;35:1948-57.

19. Kim YY, Choi H, Segami S, Cho HT, Martinoia E, Maeshima M, Lee $Y$. AtHMA1 contributes to the detoxification of excess $\mathrm{Zn}(\mathrm{II})$ in Arabidopsis. Plant J. 2009:58:737-53.

20. Kobayashi Y, Kuroda K, Kimura K, Southronfrancis JL, Furuzawa A, Kimura K, et al. Amino Acid Polymorphisms in strictly conserved domains of a P-type ATPase HMA5 are involved in the mechanism of copper tolerance variation in Arabidopsis. Plant Phisiol. 2008;148:969-80.

21. Abdel-Ghany SE, Müller-Moulé P, Niyogi KK, Pilon M, Shikanai T. Two P-type ATPases are required for copper delivery in Arabidopsis thaliana chloroplasts. Plant Cell. 2005;17:1233-51.

22. Binder BM, Rodríguez FI, Bleecker AB. The copper transporter RAN1 is essential for biogenesis of ethylene receptors in Arabidopsis. J Biol Chem. 2010;285:37263-70.

23. Wong CK, Cobbett CS. HMA P-type ATPases are the major mechanism for root-to-shoot cd translocation in Arabidopsis thaliana. New Phytol. 2009;181: $71-8$

24. Morel M, Crouzet J, Gravot A, Auroy P, Leonhardt N, Vavasseur A, et al. AtHMA3, a P1B-ATPase allowing $\mathrm{cd} / \mathrm{Zn} / \mathrm{Co} / \mathrm{Pb}$ vacuolar storage in Arabidopsis. Plant Physiol. 2009;149:894-904

25. Wong CK, Jarvis RS, Sherson SM, Cobbett CS. Functional analysis of the heavy metal binding domains of the $\mathrm{Zn} / \mathrm{cd}$-transporting ATPase, HMA2, in Arabidopsis thaliana. New Phytol. 2009:181:79-88.

26. Suzuki M, Bashir K, Inoue H, Takahashi M, Nakanishi H, Nishizawa NK. Accumulation of starch in Zn-deficient rice. Rice. 2012:5:9.

27. Lee $S$, Kim Y, Lee Y, An G. Rice P1B-type heavy-metal ATPase, OsHMA9, is a metal efflux protein. Plant Physiol. 2007;145:831-42.

28. Shao JF, Xia J, Yamaji N, Shen RF, Ma JF. Effective reduction of cadmium accumulation in rice grain by expressing OsHMA3 under the control of the OsHMA2 promote. J Exp Bot. 2018;69:2743-52.

29. Tezuka K, Miyaadte H, Katou K, Kodama I, Matsumoto S, Kawamoto T, et al, A single recessive gene controls cadmium translocation in the cadmium hyperaccumulating rice cultivar Cho-Ko-Koku. Theor Appli Genet. 2010;120: 1175-82.

30. Ueno D, Yamaji N, Kono I, Huang CF, Ando T, Yano M, et al. Gene limiting cadmium accumulation in rice. Proc Natl Acad Sci U S A. 2010;107:16500-5.

31. Huang XY, Deng F, Yamaji N, Pinson ARM, Fujii-Kashino M, Danku J, et al. A heavy metal P-type ATPase OsHMA4 prevents copper accumulation in rice grain. Nat Commun. 2016;7:12138.

32. Deng F, Yamaji N, Xia J, Ma JF. A member of the heavy metal P-type ATPase OsHMA5 is involved in xylem loading of copper in rice. Plant Physiol. 2013;163:1353-62

33. Wang J, Li H, Zou D, Zhao J, Fan L, Wu T. Transcriptome profile analysis of cadmium tolerance in Chinese flowering cabbage. Hortic Environ Biotechnol. 2017;58:56-65.

34. Liu H, Zhao H, Wu LH, Liu A, Zhao FJ, Xu WZ. Heavy metal ATPase 3 (HMA3) confers cadmium hypertolerance on the cadmium/zinc hyperaccumulator sedum plumbizincicola. New Phytol. 2017;215:687.

35. Zhang $\mathrm{JH}$, Zeng L, Sun HL, Wu H, Chen SY. Adversity stress-related responses at physiological attributes, transcriptional and enzymatic levels after exposure to cu in Lycopersicum esculentm seedlings. Scientia Hortic. 2017:222:213-20.

36. Oono Y, Yazawa T, Kanamori H, Sasaki H, Mori S, Handa H, et al. Genomewide transcriptome analysis of cadmium stress in rice. BioMed Res Intern. 2016:9739505-5.

37. Gallusci P, Dai Z, Genard M, Gauffretau A, Leblancfournier N, Richardmolard

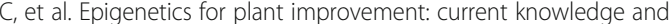
modeling avenues. Trends Plant Sci 2017; 610-623. 
38. Feng SJ, Liu XS, Tao H, Tan SK, Chu SS, Oono Y, et al. Variation of DNA methylation patterns associated with gene expression in rice (Oryza sativa) exposed to cadmium. Plant Cell Environ. 2016;39:2629-49.

39. Sebastian A, Prasad MNV. Cadmium minimization in rice. A review. Agron Sustain Dev. 2014;34:155-73.

40. Mitra A, Chatterjee S, Moogouei R, Gupta D. Arsenic accumulation in Rice and probable mitigation approaches: a review. Agronomy. 2017;7:67.

41. Ou X, Zhang Y, Xu C, Lin X, Zang Q, Zhuang T, et al. Transgenerational inheritance of modified DNA methylation patterns and enhanced tolerance induced by heavy metal stress in Rice (Oryza sativa L.). PLoS One. 2012;7: e41143.

42. Ding $Y$, Wang $X$, Su LB, Zhai J, Cao S, Zhang D, et al. SDG714, a histone H3K9 methyltransferase, is involved in Tos17 DNA methylation and transposition in rice. Plant Cell. 2007;19:9-22.

43. Ou X, Zhuang T, Yin W, Miao Y, Wang B, Zhang Y, et al. DNA methylation changes induced in rice by exposure to high concentrations of the nitric oxide modulator, sodium Nitroprusside. Plant Mol Biol Rep. 2015;33: $1428-40$.

44. Satoh-Nagasawa N, Mori M, Nakazawa N, Kawamoto T, Nagato Y, Sakurai K, et al. Mutations in rice (Oryza sativa) heavy metal ATPase2 (OsHMA2) restrict the translocation of zinc and cadmium. Plant Cell Physiol. 2012;53:213-24.

45. Miyadate H, Adachi S, Hiraizumi A, Tezuka K, Nakazawa N, Kawamoto T, et al. OsHMA3, a P1Btype of ATPase affects root-to-shoot cadmium translocation in rice by mediating efflux into vacuoles. New Phytol. 2011; 189:190-9.

46. Kabir AH. Biochemical and molecular changes in rice seedlings (Oryza sativa L.) to cope with chromium stress. Plant Biol. 2016;18:710-9.

47. Sasaki A, Yamaji N, Ma JF. Overexpression of OsHMA3 enhances cd tolerance and expression of Zn transporter genes in rice. J Exp Bot. 2014:65:6013-21.

48. Yan J, Wang P, Wang P, Yang M, Lian XM, Tang Z, et al. A loss-of-function allele of OsHMA3 associated with high cadmium accumulation in shoots and grain of Japonica rice cultivars. Plant Cell Environ. 2016:39:1941-54.

49. Khan Ml, Khan NA. Ethylene reverses photosynthetic inhibition by nickel and zinc in mustard through changes in PS II activity, photosynthetic nitrogen use efficiency, and antioxidant metabolism. Protoplasma. 2014;251: 1007-19.

50. Khan MI, Nazir F, Asgher M, Per TS, Khan NA. Selenium and sulfur influence ethylene formation and alleviate cadmium-induced oxidative stress by improving proline and glutathione production in wheat. J Plant Physiol. 2015:9-18.

51. Thao NP, Khan MI, Thu NB, Hoang XL, Asgher M, Khan NA, et al. Role of ethylene and its cross talk with other signaling molecules in plant responses to heavy metal stress. Plant Physiol. 2015;169:73-84.

52. Avramova Z. Transcriptional 'memory' of a stress: transient chromatin and memory (epigenetic) marks at stress response genes. Plant J. 2015;83:14959.

53. Liu R, How-Kit A, Srammitti L, Teyssier E, Rolin D, Mortain-Bertrand A, et al. A DEMETER-like DNA demethylase governs tomato fruit ripening. Proc Natl Acad Sci U S A. 2015;112:10804-9.

54. Correia B, Valledor L, Meijón M, Rodriguez JL, Dias MC, Santos C, et al. Is the interplay between epigenetic markers related to the acclimation of cork oak plants to high temperatures? PLoS One. 2013;8:e53543.

55. González RM, Ricardi MM, Lusem ND. Epigenetic marks in an adaptive water stress-responsive gene in tomato roots under normal and drought conditions. Epigenetics. 2013:8:864-72.

56. Diez CM, Roessler K, Gaut BS. Epigenetics and plant genome evolution. Curr Opin Plant Biol. 2014;18:1-8.

57. Li H, Yan SH, Zhao L, Tan JJ, Zhang Q, Gao F, et al. Histone acetylation associated up-regulation of the cell wall related genes is involved in salt stress induced maize root swelling. BMC Plant Biol. 2014;14:105.

58. Dai LF, Chen YL, Luo XD, et al. Level and pattern of DNA methylation changes in rice cold tolerance introgression lines derived from Oryza rufipogon Griff. Euphytica. 2015;205:73-83.

59. Yong-Villalobos L. Methylome analysis reveals an important role for epigenetic changes in the regulation of the Arabidopsis response to phosphate starvation. Proc Natl Acad Sci U S A. 2015;112:E7293-302

60. Kawashima T, Berger F. Epigenetic reprogramming in plant sexual reproduction. Nat Rev Genet. 2014;15:613-24.

61. Wibowo A, Becker C, Marconi G, Durr J, Price J, Hagmann J, et al. Hyperosmotic stress memory in Arabidopsis is mediated by distinct epigenetically labile sites in the genome and is restricted in the male germline by DNA glycosylase activity. Elife. 2016;5:e13546.

62. Pecinka A, Mittelsten Scheid O. Stress-induced chromatin changes: a critical view on their heritability. Plant Cell Physiol. 2012:53:801-8.

63. Saze $H$. Transgenerational inheritance of induced changes in the epigenetic state of chromatin in plants. Genes Genetic Syst. 2012;87:145-52.

64. Probst AV, Mittelsten SO. Stress-induced structural changes in plant chromatin. Curr Opin Plant Biol. 2015;27:8-16.

65. Makarevitch I, Waters AJ, West PT, Stitzer M, Hirsch CN, Ross-ibarra J, et al. Transposable elements contribute to activation of maize genes in response to abiotic stress. PLoS Genet. 2015:11:e1004915.

66. Rasmann S, Vos MD, Casteel CL, Tian DL, Halitschke R, Sun JY, et al. Herbivory in the previous generation primes plants for enhanced insect resistance. Plant Physiol. 2012;158:854-63.

67. Grossniklaus U, Kelly WG, Fergusonsmith AV, Pembrey M, Lindquist S. Transgenerational epigenetic inheritance: how important is it? Nat Rev Genet. 2013;14:228-35.

68. Baulcombe DC, Dean C. Epigenetic regulation in plant responses to the environment. Cold Spring Harb Perspect Biol. 2004;6:a019471.

69. Kinoshita T, Seki M. Epigenetic memory for stress response and adaptation in plants. Plant Cell Physiol. 2004;55:1859-63.

70. Liu ZL, Han FP, Tan M, Shan XH, Dong ZY, Wang XZ, et al. Activation of a rice endogenous retrotransposon Tos 17 in tissue culture is accompanied by cytosine demethylation and causes heritable alteration in methylation pattern of flanking genomic regions. Theor Appl Genet. 2004;109:200-9.

71. Ngezahayo F, Xu C, Wang HY, Jiang LL, Pang JS, Liu B. Tissue culture induced transpositional activity of mPing is correlated with cytosine methylation in rice. BMC Plant Biol. 2009;9:91.

72. Kidwell KK, Osborn TC. Simple plant DNA isolation procedures. (Dordrecht: The Netherlands: Kluwer Academic Publishers). Springer Netherlands. 1992 P.1-13.

\section{Publisher's Note}

Springer Nature remains neutral with regard to jurisdictional claims in published maps and institutional affiliations.

\section{Ready to submit your research? Choose BMC and benefit from:}

- fast, convenient online submission

- thorough peer review by experienced researchers in your field

- rapid publication on acceptance

- support for research data, including large and complex data types

- gold Open Access which fosters wider collaboration and increased citations

- maximum visibility for your research: over $100 \mathrm{M}$ website views per year

At $\mathrm{BMC}$, research is always in progress.

Learn more biomedcentral.com/submissions 